\title{
Hepatic coccidiosis in Serrasalmus rhombeus Linnaeus, 1766 from the Amazon basin: morphological and histopathological aspects
}

\section{Coccidiose hepática em Serrasalmus rhombeus Linnaeus, 1766 da Amazônia paraense: aspectos morfológicos e histopatológicos}

Jhonata Eduard Farias de Oliveira1; Rayline Thaimenne Alves Figueredo²; José Ledamir Sindeaux-Neto ${ }^{3}$; Maria do Perpétuo Socorro Progene Vilhena4; José Francisco Berrêdo5; Edilson Matos ${ }^{1,3}$; Michele Velasco ${ }^{6 \star}$

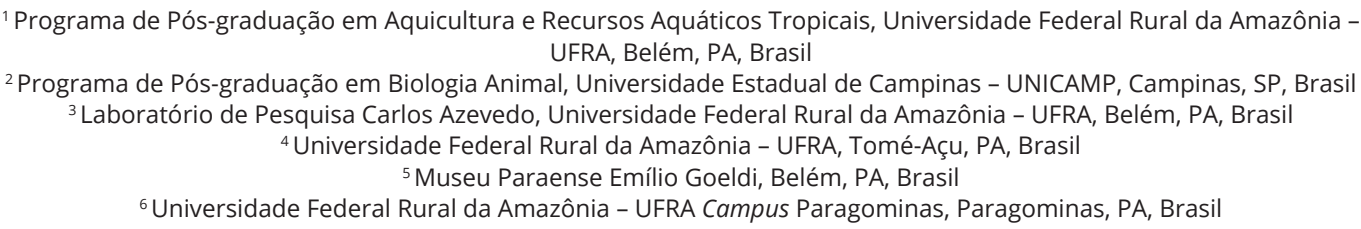

How to cite: Oliveira JEF, Figueredo RTA, Sindeaux-Neto JL, Vilhena MPSP, Berrêdo JF, Matos E, et al. Hepatic coccidiosis in Serrasalmus rhombeus Linnaeus, 1766 from the Amazon basin: morphological and histopathological aspects. Braz J Vet Parasitol 2021; 30(1): e026120. https://doi.org/10.1590/S1984-29612021007.

\begin{abstract}
Calyptospora species are coccids that commonly cause liver infections in fish all around the world. This paper describes the morphology and histopathological characteristics of liver infection caused by Calyptospora sp. in black piranha Serrasalmus rhombeus, from the Capim River, in the municipality of Ipixuna do Pará, state of Pará (Brazil). Specimens were collected, analyzed and necropsied and tissue fragments containing parasites were prepared for histology and scanning electron microscopy. Parasitism was detected in $33.0 \%$ of the analyzed specimens, which had spherical oocysts in the liver, with four pyriform sporocysts presenting sporozoites internally. A histological examination revealed oocysts positioned close to blood vessels, causing necrosis and degeneration of hepatic parenchyma, while the presence of mononuclear cell infiltrate and melanomacrophages indicated the onset of an inflammatory process. This is the first record of the genus Calyptospora in fish from the Capim River.
\end{abstract}

Keywords: Amazon basin, Calyptospora, histopathology, piranha.

\section{Resumo}

Calyptosporídeos são coccídeos constantemente encontrados causando infecções hepáticas em peixes de todo o planeta. Este estudo descreve a morfologia e características histopatológicas da infecção hepática causada por Calyptospora sp. encontrados em Serrasalmus rhombeus, a piranha negra, oriunda do rio Capim, em Ipixuna do Pará, Brasil. Os animais foram coletados, analisados e necropsiados; fragmentos teciduais com a presença dos parasitos foram processados para histologia e microscopia eletrônica de varredura. O parasitismo ocorreu em 33,0\% dos espécimes analisados, onde foram encontrados oocistos esféricos no fígado, com esporocistos piriformes, apresentando internamente esporozoítos. No exame histológico, os oocistos estavam dispostos próximos aos vasos sanguíneos, causando necrose e degeneração do parênquima hepático; a presença de infiltrado de células mononucleares e melanomacrófagos indicaram o início de um processo inflamatório. Este é o primeiro registro do gênero Calyptospora em peixes do rio Capim.

Palavras-chave: Amazônia, Calyptospora, histopatologia, piranha.

Received November 10, 2020. Accepted January 21, 2021

Financial support: Scholarship PQ 1 D CNPq Process 310068 / 2019-3 and PVNS UNIFAP / CAPES Process 8887.314368/2019-00.

*Corresponding author: Michele Velasco Oliveira da Silva. E-mail: michele.velasco.mv@gmail.com 


\section{Introduction}

Coccids, a subclass of the phylum Apicomplexa, are intracellular parasites that have a wide variety of host fish, from Chondrichthyes (elasmobranches) to Osteicthyes, which are represented by freshwater and saltwater teleosts that occur worldwide (Dyková \& Lom, 1981; Davies \& Ball, 1993; Molnár, 2006). In fact, there is phylogenetic evidence that coccids of terrestrial vertebrate emerged from fish coccidian strains (Rosenthal et al., 2016).

The family Calyptosporidae is represented by species with a heteroxenous life cycle, where by the oocysts are transmitted from the intermediate host, an invertebrate, to the definitive host, the fish (Overstreet et al., 1984; Whipps et al., 2012). The genus Calyptospora Overstreet, Hawkins and Fournie, 1984 is known to cause mainly liver pathologies, but it can also be found in the pancreas, gallbladder, mesentery, gonads and other tissues (Overstreet \& Hawkins, 2017; Ramos et al., 2018; Negrão et al., 2019).

Five species are currently described in Brazil: Calyptospora tucunarensis (Békési \& Molnár, 1991), Calyptospora spinosa (Azevedo et al., 1993), Calyptospora serrasalmi (Cheung et al., 1986), Calyptospora gonzaguensis (Silva et al., 2020) and Calyptospora paranaidji (Da Silva et al., 2019), and four of them are reported in fish from the Amazon basin. According to Da Silva et al. (2019), this region has great potential for the discovery of new calyptosporid species.

Serrasalmus rhombeus Linnaeus, 1766 stands out among the ichthyofauna of the Amazon basin. Commonly known as black or red-eyed piranha, its carnivorous habits render it notoriously aggressive. This species is part of the family Serrasalmidae, endemic to South America, usually found in northeastern Brazil and in rivers of the Amazon basin, which local communities sell as ornamental fish (Nakayama et al., 2001; Acácio et al., 2012; Sá-Oliveira et al., 2017; Anjos et al., 2018).

This paper describes the morphology of Calyptospora sp. and histopathological aspects of hepatic coccidiosis in S. rhombeus, captured in the Capim River, in the northeast of the state of Pará, eastern Amazonia.

\section{Material and Methods}

\section{Collection and analysis of specimens}

Serrasalmus rhombeus specimens were collected (under SISBIO/ICMBio Permit No. 62276-1) in the Capim River close to the "Ribeira" community $\left(2^{\circ} 66^{\prime} 67^{\prime \prime} \mathrm{S}, 48^{\circ} 32^{\prime} 34^{\prime \prime} \mathrm{W}\right)$, located in the municipality of Ipixuna do Pará, in the northeastern part of the state of Pará (PA). Collection efforts extended from April 2018 to March 2019. Captured live specimens were placed in aerated plastic bags and taken to the Carlos Azevedo Research Laboratory at the Federal Rural University of Amazonia (UFRA), Belém, PA.

The fish were anesthetized using the MS-222 protocol (50 mg/L tricaine methanesulfonate) and then necropsied, as authorized by the institution's Ethics Committee on Animal Use, under Protocol No. 011/2014). A parasitology examination was performed using a stereomicroscope to search for lesions/cysts on the body surface and in the coelomic cavity, and the findings were confirmed under an ordinary light microscope (LM), using fresh slides.

\section{Histology}

Were small fragments of parasitized liver tissue were fixed in Davidson's fluid for a period of 24 hours, processed using paraffin techniques, 5 um thick cut and stained with Hematoxylin-Eosin (HE) and Zielh-Neelsen (ZN) (Luna, 1968).

\section{Oocyst morphometry}

Mature oocysts ( $\mathrm{n}=30$ ) were measured from images captured by a Zeiss Axiocam ICc 1 camera installed in a Zeiss Axioskop 40 microscope. Means and standard deviations were measured in micrometers $(\mu \mathrm{m})$. A morphometric comparison was made with other species described in the literature, using principal component analysis (PCA), and analyzing the following parameters: oocyst diameter (OD), sporocyst length and width (SL) and the length-to-width ratio of oocyst to sporocyst (L:W), as described by Da Silva et al. (2019) for Calyptospora. The hierarchical clustering method UPGMA was also adopted. Both analyses were performed using PAST 3.0 software (Hammer et al., 2001).

\section{Scanning Electron Microscopy (SEM)}

Fragments of parasitized liver tissue were fixed in $5 \%$ glutaraldehyde buffered with sodium cacolydate at pH 7.2 for $12 \mathrm{~h}$ at $4^{\circ} \mathrm{C}$. They were then washed in buffer solution, fixed in $2 \% \mathrm{OsO}_{4}$ and buffered for three hours without 
varying the temperature. After this, the fragments were dehydrated in increasing ethanol and propylene oxide series, coated with a thin layer of gold and photographed in a TESCAN MIRA3 FEG-SEM field emission scanning electron microscope at the Emílio Goeldi Museum in Belém, state of Pará (Brazil).

\section{Results}

Spherical oocysts, showing characteristics inherent to the genus Calyptospora, were found in the liver of 05 of the 15 analyzed $S$. rhombeus specimens, representing 33.0\% of the specimens.

The oocysts had a diameter of $17.4 \pm 1.0$ (15.7-19) (Figure 1A, 2B and 3A), with four pyriform sporocysts in the shape of "bowling pins" (Figure 1B, 2 A and B), $8.33 \pm 1.1$ (6-10) in length and $4.29 \pm 0.83$ (3-4.68) in width. The oocysts, which were arranged perpendicularly and covered by a thin membranous veil-like layer, and in the internal region of the sporocysts, two sporozoites were present (Figure 1C and 3A). A suture was visible in the apical region of the external surface (Figure 2B and D, 3B), while the posterior part contained several lateral projections, the sporopods (Figure 2C, 3B). These morphological traits are characteristic of the genus Calyptospora (Overstreet et al., 1984).

The first two axes in the PCA, which explained $92.1 \%$ of the variance, were influenced mainly by the length-towidth ratio of oocyst to sporocyst. The Calyptospora sp. identified in this study was similar to Calyptospora sp. 4 and C. gonzaguensis, although this relationship was negative to the other species on both axes (Figure 4). This aspect was confirmed in the similarity dendrogram, indicating that the Euclidean distance between Calyptospora sp. 4 and C. gonzaguensis was smaller, compared to Calyptospora sp. (Figure 5).

The histological results revealed oocyst clusters close to blood vessels in the hepatic parenchyma (Figure $6 \mathrm{~A}-\mathrm{F}$ ), showing tissue degeneration, localized liver fibrosis and compression necrosis, with hepatic cells exhibiting pyknotic nuclei and lacey cytoplasm (Figure 6A and 6D). Note the presence of mononuclear cell infiltrates surrounded the oocysts, indicating a mild inflammatory process (Figure 6A and 6C), as well as melanomacrophages in both types of stains (Figure 6B and 6F).
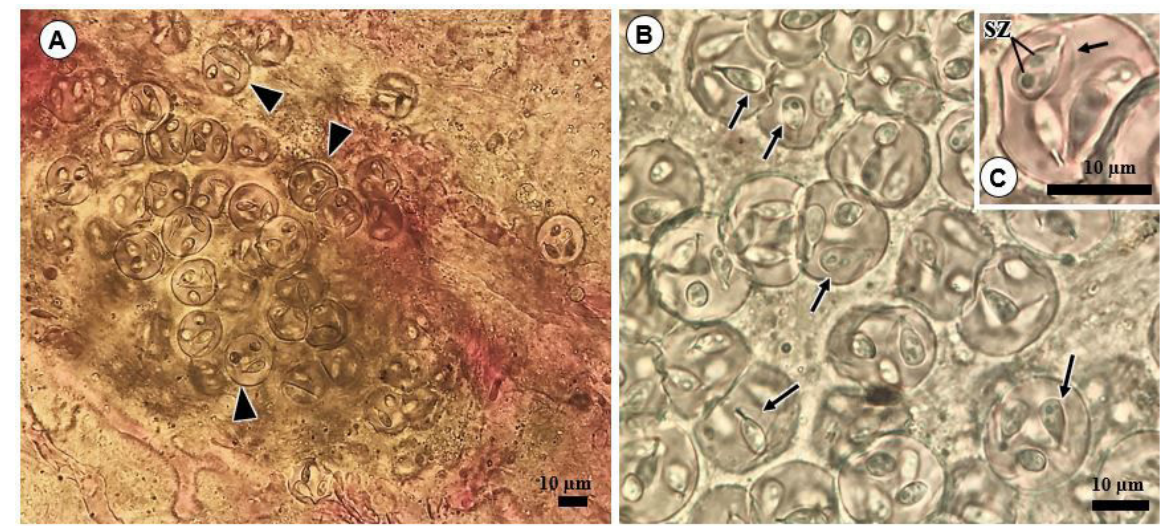

Figure 1. Light microscope images of infection by Calyptospora sp. in Serrasalmus rhombeus. A: Clusters of Calyptospora sp. oocysts in the liver; B: The arrowhead indicates sporocysts inside oocysts; C: Highlight of the sporocyst structure, with sporozoites (SZ) and membranous veil (arrowhead).
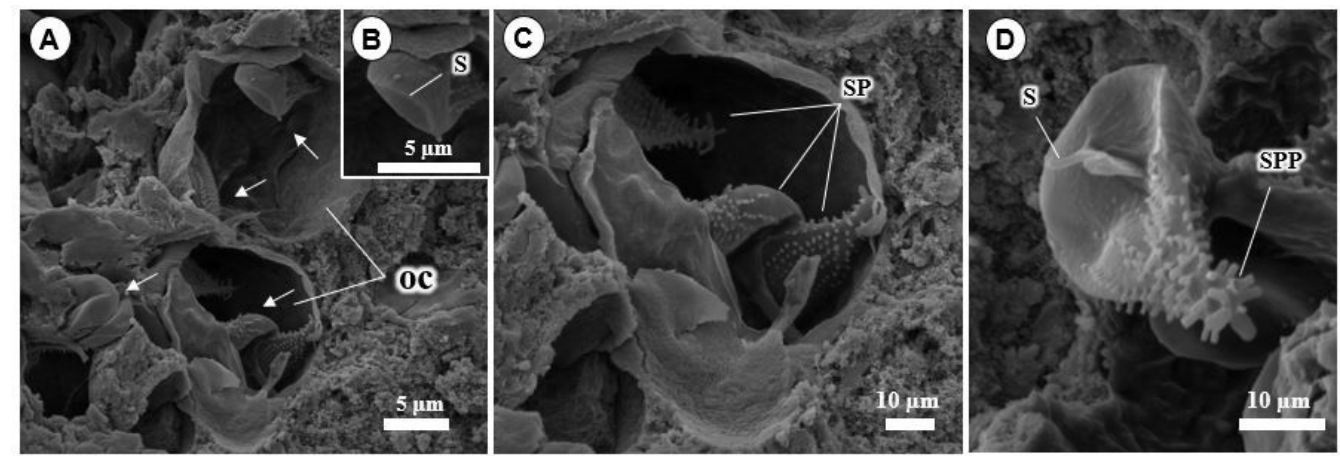

Figure 2. Scanning electron microscopy micrographs of Calyptospora sp. in the liver of Serrasalmus rhombeus. A: Oocysts (oc) composed of 4 sporocysts (arrow). B-D: Sporocyst (sp), with emphasis on the suture (s) and sporopods (spp). 

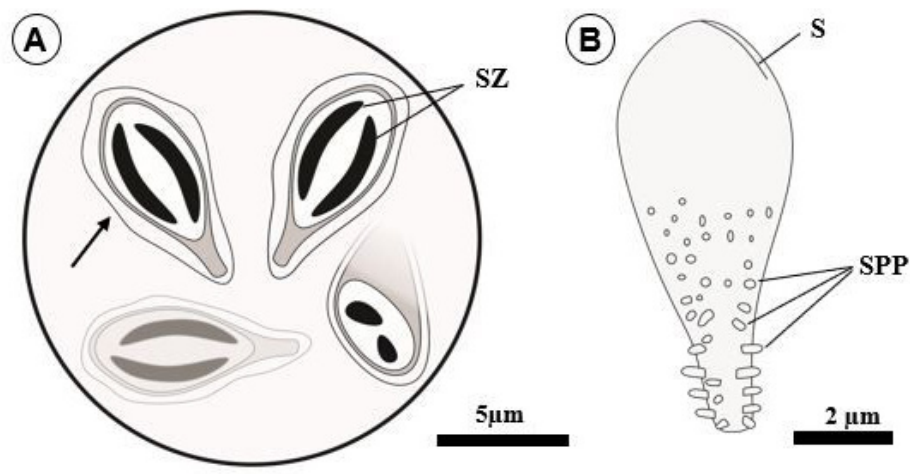

Figure 3. Schematic drawings of the oocyst and sporocyst, respectively. A: Oocyst containing 4 sporocysts, each surrounded by a membranous veil (arrow) and containing two sporozoites (sz); B: Details of the external structure of the sporocysts, with the presence of a suture (s) and sporopods (spp).

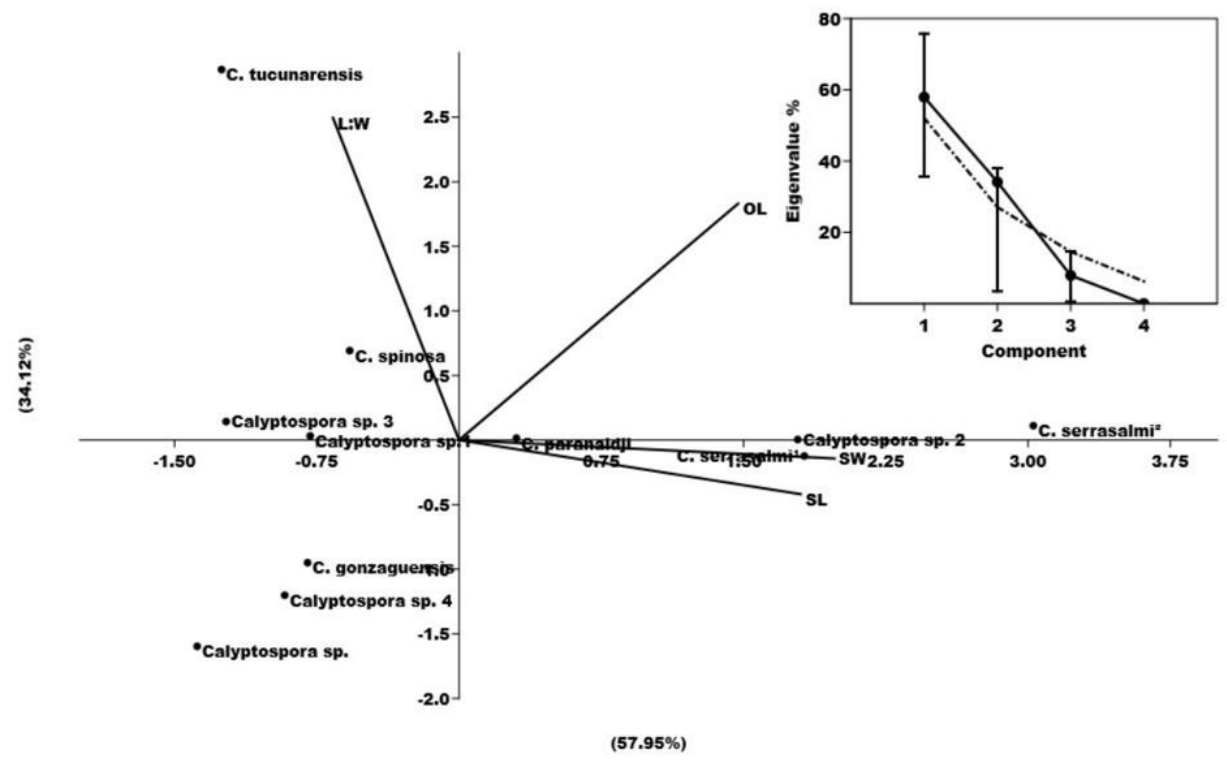

Figure 4. Principal component analysis (PCA). Oocyst length (OL); Sporocyst length (SL); length-to-width ratio of oocyst to sporocyst $(\mathrm{L}: \mathrm{W})$.

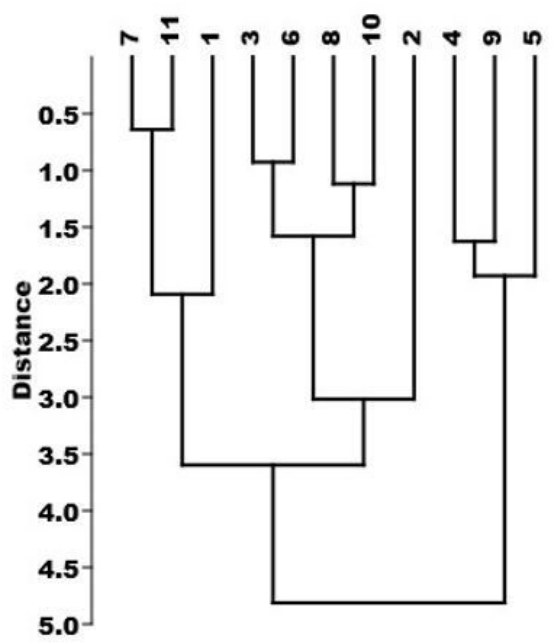

Figure 5. Dendogram of similarity. 1- Calyptospora sp.; 2- C. tucunarensis; 3- C. spinosa; 4- C. serrasalmi ${ }^{1}$; 5- C. serrasalmi ${ }^{2}$; 6- C. paranaidji; 7- C. gonzaguensis; 8-Calyptospora sp. ${ }^{1}$; 9- Calyptospora sp. ${ }^{2} ; 10$ - Calyptospora sp. ${ }^{3}$; 11 - Calyptospora sp. ${ }^{4}$ 

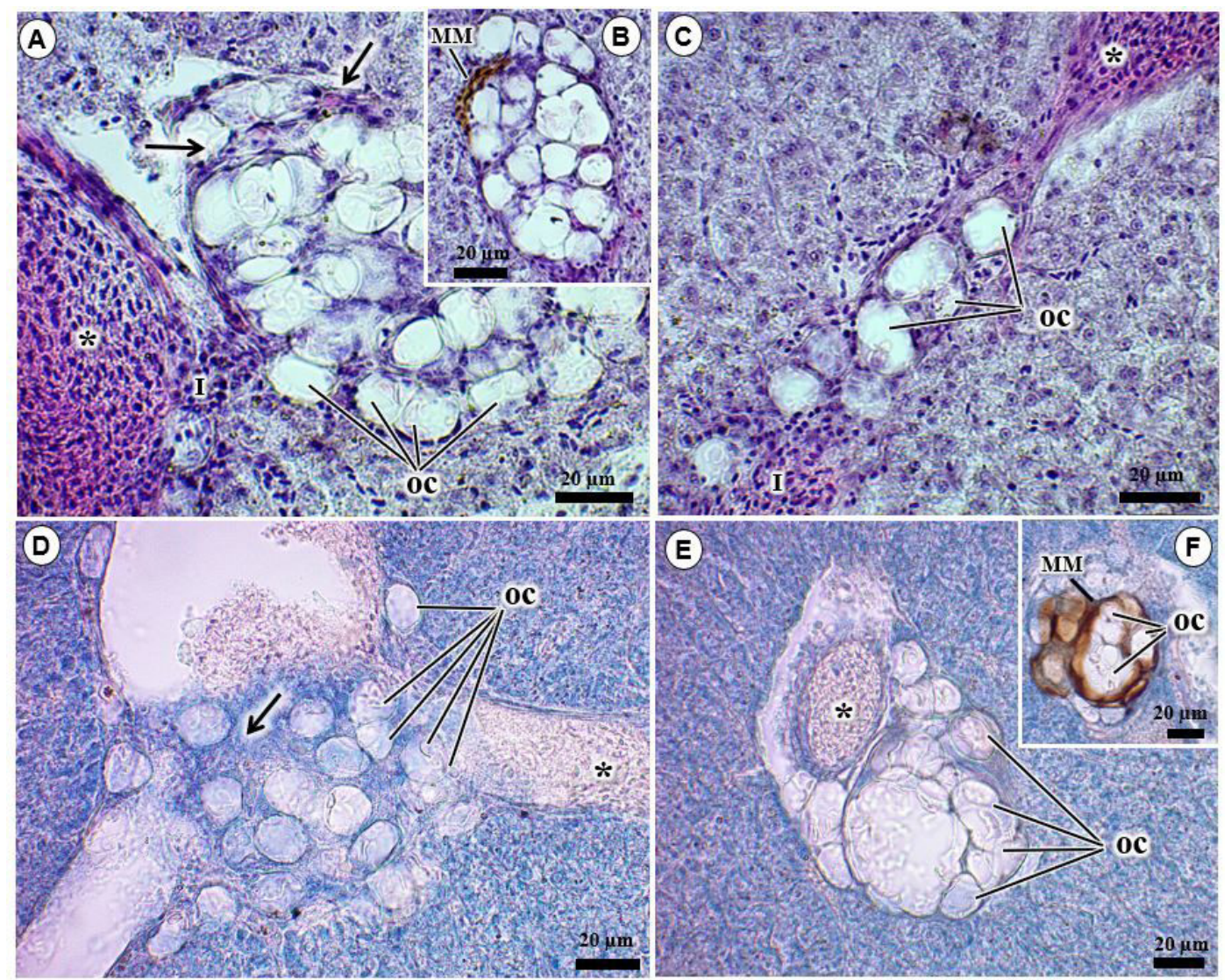

Figure 6. Histological sections of Serrasalmus rhombeus liver infected by Calyptospora sp. Oocysts (OC) disseminated in the liver tissue close to blood vessels (*), with the presence of fibroblasts (arrowhead) and mononuclear cell infiltrate (I) (6A, C and E). 6B and 6F indicate melanomacrophages (MM) around oocysts. 6D reveals widespread necrosis, liver degeneration (arrowhead), and the presence of red blood cells $(*)$ in microphotographs of ZN stained tissue.

\section{Discussion}

The parasite prevalence rate found in this study is lower than other infections by Calyptospora, which were reported in Cichla temensis Heckel, 1840 (56.0\%) (Santiago et al., 2012), Brachyplatystoma vaillantii Valenciennes, 1940 (60.0\%) (Silva et al., 2012), Crenicichla lepidota Heckel, 1840 (63.0\%) (Azevedo et al., 1993), Cichla ocellaris Bloch \& Schneider, 1801 (100\%) (Békési \& Molnár, 1991) and 100\% in carnivorous species collected by Negrão et al. (2019).

Calyptosporids have already been described causing liver infections in Serrasalmus niger, Serrasalmus striolatus and S. rhombeus, the host species in this study, presenting specificity for Calyptospora serrasalmi (Cheung et al., 1986; Casal et al., 2007; Whipps et al., 2012; Negrão et al., 2019). The spherical shape of oocysts, pyriform shape of sporocysts, and lateral extension of the sporopods were similar to this species. However, the morphometric comparisons showed greater proximity to Calyptospora sp. 4 found in Arapaima gigas (Bonar et al., 2006) and C. gonzaguensis described in Triportheus angulatus (Silva et al., 2020), which were particularly congruent with the diameter of the oocysts, of $19 \mu \mathrm{m}$ and $19.6 \mu \mathrm{m}$, respectively (Table 1).

The histopathological examination revealed oocyst clusters in the liver parenchyma adjacent to blood vessels. This is a typical histopathological finding of Calyptospora and has been described in several studies (Békési \& Molnár, 1991; Ramos et al., 2018; Velasco et al., 2012; Santiago et al., 2012). However, minor variations occur, with some species showing tropism only in blood vessels, as observed in C. gonzaguensis, or only in the liver parenchyma, such as C. paranaidji (Silva et al., 2020; Da Silva et al., 2019).

In more intense infections, the liver changes to a visibly lighter color (Videira et al., 2013; Velasco et al., 2012), resulting from the degeneration of liver tissue. As the oocysts proliferate, they cause inflammation and formation of granulomas coated with fibrous tissue (Ramos et al., 2018; Fournie \& Overstreet, 1993; Solangi \& Overstreet, 1980). According to Azevedo et al. (1993), the damage caused by Calyptospora becomes more evident at the cellular level, with cells adjacent to the oocysts presenting morphological changes such as hypertrophy and destruction of cytoplasmic structures. Similar results were found in this study. 
Table 1. Morphometric comparison of Calyptospora spp. oocysts and sporocysts described in fish species from Brazil.

\begin{tabular}{|c|c|c|c|c|c|c|c|}
\hline \multirow{2}{*}{ Species } & \multirow{2}{*}{ OD } & \multirow{2}{*}{ L:W } & \multirow{2}{*}{ Shape } & \multicolumn{2}{|c|}{ Sporocyst ( $\mu \mathrm{m})$} & \multirow{2}{*}{ CS/IS } & \multirow{2}{*}{ References } \\
\hline & & & & Length & Width & & \\
\hline Calyptospora sp. & $17.4(1.0)$ & 2.1 & Pyriform & $8.3(1.1)$ & $4.3(0.8)$ & Pará/Liver & This study \\
\hline $\begin{array}{l}\text { Calyptospora } \\
\text { tucunarensis }\end{array}$ & $24.3(2.1)$ & 2.9 & Ellipsoidal & $8.3(1.3)$ & $3.7(1.1)$ & Ceará/Liver & $\begin{array}{c}\text { (Békési \& Molnár, } \\
\text { 1991) }\end{array}$ \\
\hline Calyptospora spinosa & $22.3(1.6)$ & 2.4 & Ellipsoidal & $9.3(0.4)$ & $3.8(0.4)$ & $\begin{array}{l}\text { Pará/Liver, Gonads } \\
\text { and ovary. }\end{array}$ & (Azevedo et al., 1993) \\
\hline Calyptospora serrasalmi ${ }^{1}$ & $23.5(2.1)$ & 2.2 & Pyriform & $10.7(1.1)$ & $5.5(0.5)$ & $\begin{array}{l}\text { Amazonas and } \\
\text { Pernambuco/Liver }\end{array}$ & (Cheung et al., 1986) \\
\hline Calyptospora serrasalmi² & $25.4(0.6)$ & 2.2 & Pyriform & $11.7(1)$ & $5.9(0.4)$ & Pará/Liver & (Casal et al., 2007) \\
\hline Calyptospora paranaidji & $22.1(1.5)$ & 2.3 & Pyriform & $9.7(0.5)$ & $4.6(0.6)$ & Maranhão/Liver & (Da Silva et al., 2019) \\
\hline $\begin{array}{l}\text { Calyptospora } \\
\text { gonzaguensis }\end{array}$ & $19.6(1.4)$ & 2.1 & Pyriform & $9.2(0.6)$ & $3.9(0.2)$ & $\begin{array}{c}\text { Maranhão/Liver, gall } \\
\text { bladder and fatty } \\
\text { tissue }\end{array}$ & (Silva et al., 2020) \\
\hline Calyptospora sp. 1 & 20.8 & 2.3 & Pyriform & 8.9 & 4.1 & Pará/Liver & (Silva et al., 2012) \\
\hline Calyptospora sp. 2 & 24.5 & 2.1 & Ellipsoidal & 11.5 & 4.5 & $\begin{array}{l}\text { Minas Gerais /Liver } \\
\text { and Intestines }\end{array}$ & $\begin{array}{c}\text { (Albuquerque \& } \\
\text { Brasil-Sato, 2010) }\end{array}$ \\
\hline Calyptospora sp. 3 & 21.2 & 2.3 & Pyriform & 9.2 & 3.1 & $\begin{array}{c}\text { Manaus/ } \\
\text { Hepatopancreas }\end{array}$ & (Santiago et al., 2012) \\
\hline Calyptospora sp. 4 & 19.0 & 2.1 & Pyriform & 9 & 4 & Brazil/ Liver & (Bonar et al., 2006) \\
\hline
\end{tabular}

Note: Oocyst Diameter (OD); length-to-width ratio of oocyst to sporocyst (L:W); Collection Site (CS); Infection Site (IS).

Inflammatory infiltrate and the presence of mononuclear cells surrounding the oocysts were also described by Velasco et al. (2012), Ramos et al. (2018) and Santiago et al. (2012). Melanomacrophages were also found close to oocysts. These phagocytic cells belong to the host's innate immune system and are a common cell type usually found in fish liver infections. In such infections, these cells are part of the reticuloendothelial system and their function is to eliminate pathogens that use the bloodstream to reach the target organ/tissue where their life cycle is completed (Agius, 1985; Steinel \& Bolnick, 2017).

Susceptibility to parasitism, as well as the degree of pathogenicity, may depend on ecological factors, as was observed in an experiment with induced C. funduli infections in Atheriniformes fish, where environmental conditions and geographical isolation acted as barriers to the prevalence of parasites in each species (Fournie et al., 2000).

The histopathological data indicated that although the prevalence of parasitism by Calyptospora sp. was not high, significant pathological changes occurred in the host's liver tissue. These changes may give rise to functional abnormalities in the liver, threatening the host's survival in nature.

\section{Acknowledgements}

The authors gratefully acknowledge the financial support of CAPES, Brazil's Federal Agency for the Support and Improvement of Higher Education and the Federal Rural University of Amazonia - UFRA for enabling this study.

\section{References}

Acácio M, Varella ÂMB, Malta JCO. The parasitic crustaceans of Serrasalmus rhombeus (Linnaeus, 1776) (Characiformes: Serrasalmidae) from floodplain lakes of the Solimões River, Central Amazon, Brazil. Neotrop Helmintho/ 2012; 6(2): $179-184$.

Agius C. The melano-macrophage centres of fish: a review. In: Manning MJ, Tatner MF. Fish Immunology. 1st ed. Cambridge: Academic Press; 1985. p. 85-105. http://dx.doi.org/10.1016/B978-0-12-469230-5.50011-8. 
Anjos HDB, Amorim RMS, Siqueira JA, Anjos CR. Ornamental fish export of the State of Amazonas, Amazon Basin, Brazil. Bol Inst Pesca 2018; 35(2): 259-274.

Azevedo C, Matos P, Matos E. Morphological data of Calyptospora spinosa n. sp. (Apicomplexa, Calyptosporidae) parasite of Crenicichla lepidota Heckel, 1840 (Teleostei) from Amazon River. Eur J Protistol 1993; 29(2): 171-175. http://dx.doi.org/10.1016/ S0932-4739(11)80270-1. PMid:23195539.

Albuquerque MC, Brasil-Sato MC. First report of Calyptospora sp. (Apicomplexa, Calyptosporidae) in forage characid fish from the Três Marias Reservoir, São Francisco Basin, Brazil. EurJ Protisto/ 2010; 46(2): 150-152. http://dx.doi.org/10.1016/j.ejop.2009.12.005. PMid:20163938.

Békési L, Molnár K. Calyptospora tucunarensis n. sp. (Apicomplexa: Sporozoea) from the liver of tucunare Cichla ocellaris in Brazil. Syst Parasitol 1991; 18(2): 127-132. http://dx.doi.org/10.1007/BF00017665.

Bonar CJ, Poynton SH, Schulman FY, Rietcheck RL, Garner MM. Hepatic Calyptospora sp. (Apicomplexa) infection in a wild-born, aquarium-held clutch of juvenile arapaima Arapaima gigas (Osteoglossidae). Dis Aquat Organ 2006; 70(1-2): 81-92. http://dx.doi. org/10.3354/dao070081. PMid:16875394.

Casal G, Padovan I, Matos E, Padovan P, Matos P, Guimarães A, et al. Morphological and ultrastructural redescription of Calyptospora serrasalmi Cheung, Nigrelli \& Ruggieri, 1986 (Apicomplexa: Calyptosporidae), a parasite found in two new host species of the genus Serrasalmus. Braz J Morphol Sci 2007; 101(1): 11-16.

Cheung PJ, Nigrelli RF, Ruggieri GD. Calyptospora serrasalmi sp. nov. (Coccidia: Calyptosporidae) from liver of the black piranha, Serrasalmus niger Schomburgk. J Aquaricult Aquat Sci 1986; 4(3): 54-57.

Da Silva MF, Da Silva DT, Giese EG, Hamoy IG, Matos E. Morphology and Phylogeny of Calyptospora paranaidji n. sp. (Eimeriorina: Calyptosporidae), an Apicomplexan Parasite of the Hepatic Tissue of Cichla piquiti Kullander \& Ferreira, 2006, From a Reservoir in the Brazilian Amazon Region. J Eukaryot Microbio/ 2019; 66(4): 608-616. http://dx.doi.org/10.1111/jeu.12707. PMid:30548108.

Davies AJ, Ball SJ. The biology of fish coccidia. In: Baker JR, Muller R. Advances in parasitology. 1st ed. Cambridge: Academic Press; 1993. p. 293-366.

Dyková I, Lom J. Fish coccidia: critical notes on life cycles, classification and pathogenicity. J Fish Dis 1981; 4(6): 487-505. http:// dx.doi.org/10.1111/j.1365-2761.1981.tb01161.x.

Fournie JW, Overstreet RM. Host Specificity of Calyptospora funduli (Apicomplexa: Calyptosporidae) in Atheriniform Fishes. J Parasito/ 1993; 79(5): 720-727. http://dx.doi.org/10.2307/3283611. PMid:8410544.

Fournie JW, Vogelbein WK, Overstreet RM, Hawkins WE. Life cycle of Calyptospora funduli (Apicomplexa: calyptosporidae). J Parasitol 2000; 86(3): 501-505. http://dx.doi.org/10.1645/0022-3395(2000)086[0501:LCOCFA]2.0.CO;2. PMid:10864246.

Hammer $\varnothing$, Harper DAT, Ryan PD. PAST: Paleontological statistics software package for education and data analysis. Paleotol Electronic 2001; 4(1):1-9.

Luna LG. Manual of histologic staining methods of the Armed Forces Institute of Pathology. New York: McGraw-Hill; 1968.

Molnár K. Phylum apicomplexa. In: Woo PTK, Leatherland JF. Fish diseases and disorders. 2nd ed. Cambridge: Cabi; 2006. http:// dx.doi.org/10.1079/9780851990156.0183.

Nakayama C, Jégu M, Porto JIR, Feldberg E. Karyological Evidence for a Cryptic Species of Piranha within Serrasalmus rhombeus (Characidae, Serrasalminae) in the Amazon. Copeia 2001; 2001(3): 866-869. http://dx.doi.org/10.1643/0045-8511(2001)001[0866:KE FACS]2.0.CO;2.

Negrão MCS, Silva MRL, Videira MN, Viana LA. Prevalence and molecular characterisation of Calyptospora parasites Overstreet, Hawkins and Fournié, 1984 (Apicomplexa: Calyptosporidae) in fishes from the eastern Amazon, Brazil. Parasitol Int 2019; 73: 101975. http://dx.doi.org/10.1016/j.parint.2019.101975. PMid:31421267.

Overstreet RM, Hawkins WE, Fournie JW. The Coccidian Genus Calyptospora n. g. and Family Calyptosporidae n. fam. (Apicomplexa), with Members Infecting Primarily Fishes.J Protozool 1984; 31(2): 332-339. http://dx.doi.org/10.1111/j.1550-7408.1984.tb02972.x.

Overstreet RM, Hawkins WE. Diseases and mortalities of fishes and other animals in the Gulf of Mexico. In: Ward C. Habitats and biota of the Gulf of Mexico: Before the Deepwater Horizon oil spill. 1 nd ed. New York: Springer; 2017. p. 1589-1738. http://dx.doi. org/10.1007/978-1-4939-3456-0_6.

Ramos ABMA, Santos PFS, Hemeterio LCA, Santos WJP, Araújo RS, Matos EM. Coccidiose hepática em Aspistor quadriscutis, Valenciennes, 1840 (Teleostei: Ariidae) capturados no estuário do nordeste paraense, Amazônia, Brasil. Arch Vet Sci 2018; 23(3): 63-67. http://dx.doi.org/10.5380/avs.v23i3.52244.

Rosenthal BM, Dunams-Morel D, Ostoros G, Molnár K. Coccidian parasites of fish encompass profound phylogenetic diversity and gave rise to each of the major parasitic groups in terrestrial vertebrates. Infect Genet Evol 2016; 40: 219-227. http://dx.doi. org/10.1016/j.meegid.2016.02.018. PMid:26911642. 
Santiago H, Corrêa JL, Tortelly R, Menezes RC, Matos P, Matos E. Morphology and histopathology of Calyptospora sp. (Apicomplexa: Calyptosporidae) in speckled peacock bass, Cichla temensis Humboldt, 1821 (Perciformes: Cichlidae), from the Marajó-Açu River, Marajó Island, Brazil. Parasitol Res 2012; 110(6): 2569-2572. http://dx.doi.org/10.1007/s00436-011-2770-0. PMid:22200958.

Sá-Oliveira JC, Ferrari SF, Vasconcelos HCG, Araujo AS, Campos CEC, Mattos-Dias CAG, et al. Resource Partitioning between Two Piranhas (Serrasalmus gibbus and Serrasalmus rhombeus) in an Amazonian Reservoir. Sci World J 2017; 2017: 9. http://dx.doi. org/10.1155/2017/8064126. PMid:29359177.

Silva MC, Clemente SCS, Júnior JAP, Silva MVO, Matos ER. Calyptospora sp. in Brachyplatystoma vaillantii trapped at the Vigia, State of Pará, Brazil. Rev Bras Parasitol Vet 2012; 21(2): 176-178. http://dx.doi.org/10.1590/S1984-29612012000200020. PMid:22832762.

Silva MF, Orlanda JFF, Aráujo-Costa MJ, Hamoy I, Matos E. Hepatic coccidiosis in Triportheus angulatus Spix \& Agassiz, 1829 (Characiformes: Triportheidae), a tropical fish from the eastern Brazilian Amazon, with the description of a new species of Calyptospora (Apicomplexa: Calyptosporidae). J Eukaryot Microbiol 2020; 67(3): 352-358. http://dx.doi.org/10.1111/jeu.12785. PMid:31943507.

Solangi MA, Overstreet RM. Biology and Pathogenesis of the Coccidium Eimeria funduli Infecting Killifishes. J Parasitol 1980; 66(3): 513-526. http://dx.doi.org/10.2307/3280757. PMid:7391893.

Steinel NC, Bolnick DI. Melanomacrophage centers as a histological indicator of immune function in fish and other poikilotherms. Front Immunol 2017; 8: 827. http://dx.doi.org/10.3389/fimmu.2017.00827. PMid:28769932.

Velasco M, Videira M, Matos P, São Clemente SC, Sanches O, Matos E. Morfologia e nova ocorrência de um coccídio hepatopancreático parasita de peixe amazônico. Amazon J Agric Envir Sci 2012; 55(3): 231-235. http://dx.doi.org10.4322/rca.2012.063.

Videira M, Velasco M, Tortelly R, Menezes RC, São Clemente SC, Matos E. An anatomopathological study of hepatic coccidiosis (Calyptospora sp.) in the Acará-pixuna, Aequidens plagiozonatus Kullander, 1984 from the Brazilian state of Pará. Arq Bras Med Vet Zootec 2013; 65(1): 91-94. http://dx.doi.org/10.1590/S0102-09352013000100014.

Whipps CM, Fournie JW, Morrison DA, Azevedo C, Matos E, Thebo P, et al. Phylogeny of fish-infecting Calyptospora species (Apicomplexa: eimeriorina). Parasitol Res 2012; 111(3): 1331-1342. http://dx.doi.org/10.1007/s00436-012-2969-8. PMid:22645034. 